Associate Professor Joanna Smyczyńska, MD, PhD, https:// orcid.org/0000-0002-2147-9503 Department of Pediatrics, Diabetology, Endocrinology and Nephrology

Medical University of Lodz

\title{
Promotion of reproductive and metabolic health - current trends in the treatment and prevention of polycystic ovary syndrome in different periods of life
}

\author{
Promocja zdrowia prokreacyjnego i metabolicznego - aktualne \\ kierunki w terapii i profilaktyce zespołu policystycznych jajników \\ w różnych okresach życia ${ }^{1}$ \\ https://doi.org/10.34766/fetr.v47i3.895
}

\begin{abstract}
Polycystic ovary syndrome (PCOS) is one of the most common hormonal disorders and causes of infertility in women in reproductive age. Diagnostic criteria of PCOS in adult women include: ovulation disorders, hyperandrogenism and polycystic ovaries. According to most recommendations, 2 out of these 3 criteria are confirm the diagnosis of PCOS. In girls during puberty and in the first years after menarche, different diagnostic criteria of menstrual disorders should be taken into account (variable length of menstrual cycles, monophasic cycles) and the limited usefulness of ultrasound examination for PCOS diagnosis within 8 years after menarche. Fairly extensive differential diagnosis is also necessary, especially - exclusion of adrenal hyperandrogenism. Moreover, the diagnostic criteria of PCOS do not take into account the metabolic disorders found in most patients (obesity, insulin resistance, type 2 diabetes), which should be diagnosed as early as possible and treated appropriately. This is especially true for teenagers, in whom the unequivocal diagnosis of PCOS or its exclusion may be very difficult. Current recommendations regard hormonal contraception as the first-line therapy in PCOS, in both adult women and adolescents. Together with its beneficial effect on the reduction of hyperandrogenism and obtaining regular bleeding (which in fact are not menstruations), the unfavorable metabolic effects of hormonal contraception are emphasized, as well as the inadequacy of its use if it is expected to achieve or restore ovulation and fertility. The latest reports indicate the legitimacy of treatment aimed at correcting disorders of carbohydrate metabolism and its greater effectiveness compared to the use of oral contraceptives in both adult women and girls with PCOS. In the pharmacotherapy of insulin resistance, metformin is of fundamental importance, the use of pioglitazone, GLP-1 receptor agonists or inositols is also proposed. Adequate lifestyle and dietary modification are of major importance in the treatment and prevention of PCOS. The mechanisms of "inheritance" of PCOS and insulin resistance with the participation of epigenetic modifications are still better understood, taking into account the effects of exposure to androgen excess in utero, intrauterine growth retardation, and maternal obesity and hyperalimentation. This creates new possibilities for PCOS prophylaxis.
\end{abstract}

Keywords: hyperandrogenism, insulin resistance, ovulation, polycystic ovary syndrome, procreative health

Abstrakt: Zespół policystycznych jajników (PCOS) jest jednym z najczęstszych zaburzeń hormonalnych u kobiet $\mathrm{w}$ wieku rozrodczym, a zarazem jedną z najczęstszych przyczyn niepłodności.

${ }^{1}$ Polska wersja: https:/ / stowarzyszeniefidesetratio.pl/Presentations0/2021-3-Smyc.pdf 
Kryteria rozpoznania PCOS u kobiet dorosłych obejmują: zaburzenia owulacji, hiperandrogenizm i policystyczną strukturę jajników. Według większości rekomendacji dla rozpoznania PCOS wymaganie jest spełnienie 2 spośród wymienionych 3 kryteriów. U dziewcząt $\mathrm{w}$ okresie pokwitania i w pierwszych latach po menarche należy uwzględnić odrębności dotyczące kryteriów diagnostycznych zaburzeń miesiączkowania (zmienna długość cykli miesiączkowych, występowanie cykli jednofazowych) oraz ograniczoną przydatność badania USG dla potwierdzenia rozpoznania PCOS nawet $\mathrm{w}$ ciągu 8 lat po menarche. Konieczne jest również przeprowadzenie dość szerokiej diagnostyki różnicowej, w szczególności - wykluczenie hiperandrogenizmu nadnerczowego. Ponadto, kryteria rozpoznania PCOS nie uwzględniają stwierdzanych u większości pacjentek zaburzeń metabolicznych (otyłości, insulinooporności, cukrzycy typu 2), które powinny być możliwie wcześnie rozpoznawane i odpowiednio leczone. Jest to szczególnie istotne u nastolatek, u których jednoznaczne postawienie rozpoznania PCOS bądź jego wykluczenie może być bardzo trudne. Aktualne rekomendacje uznają antykoncepcję hormonalną za terapię pierwszego rzutu w PCOS zarówno u kobiet dorosłych, jak i u nastolatek $\mathrm{z}$ zaawansowanym dojrzewaniem. Obok korzystnego wpływu na redukcję hiperandrogenizmu i uzyskania regularnych krwawień (które de facto nie są miesiączkami) podkreślane są niekorzystne efekty metaboliczne antykoncepcji hormonalnej i nieadekwatność jej stosowania, jeśli oczekiwane jest uzyskanie bądź przywrócenie cykli owulacyjnych i płodności. Najnowsze doniesienia wskazują na zasadność leczenia ukierunkowanego na wyrównanie zaburzeń gospodarki węglowodanowej oraz jego większą skuteczność w porównaniu do stosowania doustnej antykoncepcji zarówno u kobiet dorosłych, jak i u dziewcząt $\mathrm{z}$ PCOS. W farmakoterapii insulinooporności podstawowe znaczenie ma metformina, proponowane jest także stosowanie pioglitazonu, agonistów receptora GLP-1, czy inozytoli. Istotne znaczenie w leczeniu i zapobieganiu PCOS przypisuje się odpowiedniej modyfikacji stylu życia i sposobu żywienia. Coraz lepiej poznane są mechanizmy „dziedziczenia” PCOS i insulinooporności, z udziałem modyfikacji epigenetycznych, uwzgledniające wpływ ekspozycji na nadmiar androgenów w życiu płodowym, wewnątrzmacicznego zahamowania wzrastania oraz otyłości i hiperalimentacji matki w ciąży, co stwarza nowe możliwości profilaktyki PCOS.

Słowa kluczowe: hiperandrogenizm, insulinooporność, owulacja, zdrowie prokreacyjne, zespół policystycznych jajników

\section{Introduction}

Polycystic ovary syndrome (PCOS) it is one of the most commonly diagnosed endocrinopathies in women, and the first clinical description of this disease entity dates back over 85 years (Stein, Leventhal, 1935). Basic criteria for the diagnosis of PCOS include menstrual/ovulation disorders, hyperandrogenism and polycystic ovarian structure, where, according to the "Rotterdam" criteria (Fauser, 2004), any 2 of the 3 criteria are required to be met, while, according to the criteria of The Androgen Excess and PCOS Society (AE-PCOS) (Azziz, Carmina, Dewailly, Diamanti-Kandarakis, Escobar-Morreale et al., 2009) evidence of hirsutism or hyperandrogenemia is required and at least one of the other criteria must be met. Depending on the adopted diagnostic criteria, it is estimated that PCOS may affect 6-13\% of women of reproductive age (Bozdag, Mumusoglu, Zengin, Karabulut, Yildiz, 2016). Due to the occurrence of oligoovulation or anovulation, PCOS is also one of the most common causes of female infertility. Particularly large discrepancies concern the incidence of PCOS in adolescents. In the same group of girls, AE-PCOS criteria were met by $3 \%$ of girls, while the "Rottedam" criteria by as much as 18.5\% (Hickey, Doherty, Atkinson, Sloboda, Franks et al., 2011). In more recent studies (Khashchenko, Uvarova, Vysokikh, Ivanets, 
Krechetova et al., 2020) the prevalence of PCOS in adolescents has been estimated at 2.2-7.5\%, but among girls with menstrual disorders and hirsutism it was even $68 \%$. At the same time, it is known that there is a correlation between the nutritional status and the incidence of PCOS, and this syndrome is diagnosed several times more often in obese patients than in girls with normal body weight (Christensen, Black, Smith, Martinez, Jacobsen et al., 2013). Diagnosis of PCOS requires the fulfillment of specific diagnostic criteria and the exclusion of a number of diseases with a similar course. Unfortunately, there are cases of incorrectly diagnosed women, in whom adrenal hyperandrogenism was overlooked, e.g. in case of non-classic congenital adrenal hyperplasia ( $\mathrm{CAH})$, which implies a different pathogenesis of the disease and a different treatment. On the other hand, the diagnosis of PCOS in adolescents and young women with menstrual disorders is sometimes based on the criteria appropriate for adult women, without taking into account the physiological differences regarding the normal length of the menstrual cycle and ovarian structure assessed by ultrasound (US). Such patients often receive hormonal contraception (usually in the form of combined oral pills), which allow to achieve regular bleeding (being de facto not menstruation but "withdrawal" bleedings), and often also at least partial reduction of the symptoms of hyperandrogenism. Such management, however, does not take into account the significant role of metabolic disorders in the pathogenesis of PCOS, and it is also not aimed at restoring reproductive health and proper fertility potential. The results of recently published scientific studies indicate the legitimacy of using treatment aimed at correcting carbohydrate metabolism disorders in girls with PCOS. Adequate lifestyle and dietary modification are of great importance in both the treatment and preventing PCOS occurrence in every period of life.

Given the high prevalence of familial PCOS incidence in mothers and daughters, or even in several consecutive generations of women, the concept of the hereditary basis of this syndrome was put forward, which, however, has not been confirmed by the results of studies conducted in this area. Instead, factors such as exposure to excess androgens in utero, intrauterine growth retardation and related epigenetic modifications, have been shown to be of significant importance. This creates a need for endocrinological monitoring of girls born to mothers with PCOS and with other diseases that increase the risk of PCOS in female offspring. Girls with obesity, insulin resistance or premature and strongly expressed adrenal phase of sexual maturation (adrenarche) also constitute the PCOS risk group. A separate, difficult diagnostic and therapeutic problem are patients with primary amenorrhea, in whom the entire clinical picture suggests the diagnosis of PCOS.

\section{PCOS diagnostic criteria in adult women}


Polycystic ovary syndrome is diagnosed in patients with ovulation disorders (translating into secondary or, more rarely, primary amenorrhea or oligomenorrhoea), hyperandrogenism (clinical and/or laboratory) and polycystic structure of the ovaries on US examination. There are some differences in the diagnostic criteria proposed by various scientific societies. According to the most commonly used "Rotterdam" criteria of 2003, proposed jointly by the European Society of Human Reproduction and Embryology (ESHRE) and the American Society for Reproductive Medicine (ASRM) (Fauser, 2004), in adult women for the diagnosis of PCOS, at least two of the following three criteria must be met: 1 / anovulation or oligoovulation; 2/ hiperandrogenism, 3/ polycystic ovarian structure (morphology) in US examination (PCOM). The Androgen Excess and PCOS Society (Azziz et al., 2009) set somewhat different criteria, according to which the diagnosis of PCOS requires the presence of hirsutism and/or hyperandrogenemia (a sine qua non condition) and additionally - chronic anovulation or PCOM.

According to the Position Statement of the Polish Society of Endocrinology (PSE), the Polish Society of Gynecologists and Obstetricians (PTGO) and the Polish Society of Gynecological Endocrinology (PSGE) (Milewicz, Kudła, Spaczyński, Dębski, Męczekalski et al., 2018), ESHRE/ASRM criteria are recommended for the diagnosis of PCOS in adult women (Fauser, 2004), with minor modifications proposed by the authors.

It is also necessary to exclude other endocrinopathies, especially androgen excess of adrenal origin, including late-onset "non-classical" CAH and androgen-secreting tumors, as well as Cushing syndrome, acromegaly, hypothyroidism and hyperprolactinemia; in the case of secondary amenorrhea, a pregnancy test is required as well (Milewicz et al., 2018).

It is also known that PCOS patients have an abnormal, elevated gonadotropin ratio LH:FSH, which is important in the pathomechanism of ovarian dysfunction (leads to the predominance of testosterone synthesis under the influence of LH over its aromatization under the influence of FSH); this is not included in the diagnostic criteria. In the diagnostics of PCOS, it is proposed to perform a stimulation test with gonadoliberin $(\mathrm{GnRH})$, however this test should be considered only as an auxiliary procedure (Lewandowski, Cajdler-Łuba, Salata, Bieńkiewicz, Lewiński, 2011). Moreover, women with PCOS are often overweight or obese, and have disorders of carbohydrate metabolism, mainly insulin resistance, which are also not included in the diagnostic criteria of PCOS, although the reduction of excess body weight and the correction of metabolic disorders may be of key importance for the success of PCOS therapy.

\section{PCOS diagnostic criteria in the first years after menarche}

Determining the diagnosis of PCOS in girls is particularly difficult as some of the symptoms considered pathognomonic in adult women should be considered physiological 
during puberty (Milewicz et al., 2018). In the first years after menarche, menstrual cycles can be monophasic (anovulatory) and need not be regular during this period, the picture of PCOM is also normal in healthy girls. Therefore, it is assumed that in adolescents the necessary condition for the diagnosis of PCOS is confirmation of ovarian hyperandrogenism (Hecht Baldauff, Arslanian, 2015; Ibáñez, Oberfield, Witchel, Auchus, Chang et al., 2017). Few years ago, a comprehensive study, concerning pathophysiology, diagnosis and treatment of PCOS in adolescence, was published by an international consortium of authors (Ibáñez et al., 2017). The diagnostic criteria for PCOS proposed in this paper are presented in Table 1. Last year, another international evidence-based guidelines for PCOS in adolescents appeared (Peña, Witchel, Hoeger, Oberfield, Vogiatzi et al., 2020), in which the authors have proposed both the required diagnostic criteria for PCOS and a list of not recommended tests, as well as exclusion criteria. These recommendations are presented in Table 2, while the differences in the interpretation of menstrual disorders in adolescents and in the first years after menarche - in Table 3.

Table 1. PCOS diagnostic criteria in adolescents, according to Ibáñez et al. (2017)

\begin{tabular}{|c|c|c|c|}
\hline Required & Optional* & Not recommended ${ }^{* *}$ & Comments \\
\hline $\begin{array}{l}\text { Irregular mentruations, } \\
\text { oligomenorrhoea } \\
\text { Hyperandrogenism: } \\
\text { biochemical or clinical } \\
\text { (e.g. progressive } \\
\text { hirsutism) }\end{array}$ & $\begin{array}{l}\text { Polycystic ovaries } \\
\qquad \text { (PCOM) } \\
\text { Severe cystic acne }\end{array}$ & $\begin{array}{c}\text { Obesity } \\
\text { Insulin resistance } \\
\text { Hyperinsulinemia } \\
\text { Biomarkers (e.g. AMH, } \\
\text { testosterone/DHT ratio) } \\
\text { Acanthosis nigricans }\end{array}$ & $\begin{array}{c}\text { Generally must be } \\
2 \text { years post menarche } \\
\text { Must be ruled out other } \\
\text { disorders with } \\
\text { hyperandrogenism } \\
\text { (non-classic CAH, } \\
\text { Cushing syndrome) }\end{array}$ \\
\hline
\end{tabular}

*Optional criteria should be used only together with the required criteria

**Criteria associated with PCOS but not diagnostic

Abbreviations: PCOM - polycystic ovarian morphology; AMH -antymüllerian hormone; DHT dihydrotestosterone; $\mathrm{CAH}$ - congenital adrenal hyperplasia

Although in the initial period there may be mainly monophasic cycles of various lengths, their observation seems advisable, because irregular menstruation lasting more than 2 years after the menarche is considered a risk factor for menstrual disorders later in life (Witchel, Oberfield, Rosenfield, Codner, Bonny et al., 2015). Girls with PCOS may also initially experience heavy bleeding, preceding oligomenorrhoea and secondary amenorrhea (Urbańska, Hirnle, Olszanecka-Glinianowicz, Skrzypulec-Plinta, Skrzypulec-Frankel, Drosdzol-Cop, 2019). Polish authors (Milewicz et al., 2018) recommend the use of the following biomarkers for the assessment of ovulation: observation of the regularity of menstruations, ultrasound monitoring, determination of serum progesterone in the luteal phase of the cycle and measurements of basal body temperature (BBT). 
Table 2. PCOS diagnostic criteria in adolescents, according to Peña et al. (2020)

\begin{tabular}{|c|c|c|}
\hline Criteria required & $\begin{array}{c}\text { Investigations } \\
\text { not recommended }\end{array}$ & $\begin{array}{c}\text { Exclusion } \\
\text { of other conditions }\end{array}$ \\
\hline $\begin{array}{l}\text { Irregular menstrual cycles and } \\
\text { ovulatory dysfunction (age-dependent } \\
\text { interpretation, see Table 3); } \\
\text { if anovulation is suspected in } \\
\text { adolescents or women with regular } \\
\text { menstrual cycles, progesterone level } \\
\text { should be measured } \\
\text { Hyperandrogenism } \\
\text { a. biochemical (calculated free } \\
\text { testosterone concentration, free } \\
\text { androgen index) confirmed with high- } \\
\text { quality tests; in women on hormonal } \\
\text { contraception, assessment should be } \\
\text { performed after its withdrawal } \\
\text { for } 3 \text { months } \\
\text { b. clinical: moderate or severe } \\
\text { comedonal acne in early puberty, } \\
\text { moderate or severe inflammatory acne } \\
\text { in peri-menarcheal period, hirsutism } \\
\text { (assessment according to Feriman- } \\
\text { Galwey scale, no uniform cut-off } \\
\text { established) }\end{array}$ & $\begin{array}{l}\text { Pelvic USG - in patients } \\
\text { with a gynaecological age } \\
\text { of }<8 \text { years }(e . g .<8 \text { years } \\
\text { post menarche }) \text { - the high } \\
\text { incidence of polycystic } \\
\text { ovaries in healthy } \\
\text { adolescents and young } \\
\text { women; US may be } \\
\text { performed to investigate } \\
\text { other uterine or ovarian } \\
\text { abnormalities } \\
\text { AMH - lack of established } \\
\text { cut-off levels in studies on } \\
\text { large populations of } \\
\text { different ages and } \\
\text { ethnicities, } \\
\text { the necessity of improved } \\
\text { standardization } \\
\text { of assays }\end{array}$ & $\begin{array}{c}\text { Pregnancy - the most } \\
\text { common cause of } \\
\text { amenorrhea in sexually } \\
\text { active teenagers } \\
\text { Hypothalamc amenorrhoea } \\
\text { Non-classic CAH } \\
\text { (21-hydroxsylase deficiency - } \\
\text { asessment of 17-OHP in } \\
\text { follicular phase of menstrual } \\
\text { cycle, test with Synacthen) } \\
\text { Hypothyroidism } \\
\text { Hyperprolactinemia } \\
\text { Cushing syndrome } \\
\text { Glucocorticoid resistance } \\
\text { Androgen-secreting ovarian } \\
\text { and adrenal tumors }\end{array}$ \\
\hline
\end{tabular}

Abbreviations: US - ultrasonography, AMH -antimüllerian hormone, CAH - congenital adrenal hyperplasia, 17-OHP - 17-hydroxyprogesterone

Table 3. Criteria of irregular menstrual cycles in adolescents, according to Peña et al. (2020)

\begin{tabular}{|c|c|}
\hline Time post menarche & Definition of irregular menstrual cycles \\
\hline$<1$ year & Irregular cycles are normal \\
\hline $1-3$ years & $<21$ days or $>45$ days \\
\hline$>3$ years & $<21$ days or $>45$ days or $<8$ cycles $/$ year \\
\hline$>1$ year & Any single cycle $>90$ days \\
\hline Primary amenorrhea by age 15 years or $>3$ years from beginning of breast development
\end{tabular}

From a clinical point of view, particularly important is the recommendation that adolescents with symptoms suggestive of PCOS, who do not meet diagnostic criteria of this syndrome, should undergo systematic monitoring and symptomatic treatment. In patients from such a defined "risk group" of PCOS, it is recommended to reassess the regularity of 
menstruations 3 years after the menarche, while ovarian structure in US examination 8 years after the menarche (in the patients using hormonal contraception, it should be discontinued 3 months before the examinations). It is important not only to make girls and their families aware of the increased risk of PCOS, the consequences of delayed diagnosis and treatment of this syndrome, but also to avoid overdiagnosing PCOS (Peña et al., 2020).

\section{PCOS phenotypes in adult women - basics of personalized therapy}

Depending on the dominant symptoms, there are 3 basic phenotypes of PCOS: metabolic, related to hyperandrogenism and reproductive (Conway, Dewailly, DiamantiKandarakis, Escobar-Morreale, Franks et al., 2014), and the related need for personalization of therapy was clearly expressed in the common Position Statement of PSE, PTGO and PTGE (Milewicz et al., 2018). The most common is the metabolic phenotype associated with the presence of classic PCOS symptoms (i.e., fertility disorders, hyperandrogenism, and PCOM), abdominal obesity and carbohydrate metabolism disorders: insulin resistance $(40-70 \%$ of cases), glucose intolerance (30-35\% of cases), type 2 diabetes (8-10\% of cases) (Milewicz et al., 2018; Pasquali, 2006). Moreover, these patients have an increased incidence of lipid metabolism disorders, non-alcoholic fatty liver disease, and the risk of cardiovascular diseases. The next of the phenotypes mentioned is dominated by clinical and biochemical symptoms of hyperandrogenism, which may be associated with impaired fertility, PCOM and metabolic disorders. It is recommended to assess the androgen profile in girls with treatment-resistant acne or hirsutism, and in the case of particularly high testosterone levels - exclusion of an ovarian or adrenal tumor. Detailed recommendations can be found in the previously quoted Position Statement of Polish scientific societies, concerning the diagnostics and therapy of PCOS (Milewicz i in., 2018). In the case of the reproductive phenotype, the main problem are disorders of menstrual cycle (oligomenorrhoea) and of ovulation, with secondary amenorrhea and anovulation, leading to infertility. They are associated with abnormalities in folliculogenesis and PCOM. In these patients, testosterone levels and the free androgen index (FAI) may be normal or only slightly elevated, hirsutism and acne do not occur, and overweight or obesity is observed only in some cases. There are also patients who cannot be clearly assigned to one of the phenotypes.

Given the clinical differences in the course of PCOS, as well as the different age of the patients, from puberty through reproductive age up to menopause and postmenopausal period, it seems obvious that these differences should be taken into account when planning treatment. In the case of the metabolic phenotype, weight reduction and improvement of insulin sensitivity are essential, achieved through lifestyle modifications (dietary management and increased physical activity) leading to weight loss, usually in combination with pharmacotherapy. Dietary recommendations for adults with insulin resistance include 
a diet with negative balance of 500-600 kcal/ day in relation to the total energy expenditure, limiting the consumption of simple sugars (also in the form of sweet drinks and excessive amounts of fruit juices), in favor of consuming products with a low glycemic index and high in fiber (whole grains, non-starchy vegetables, raw fruit), eating calcium-rich foods (milk and dairy), reducing alcohol consumption (moderate consumption as part of a balanced lowcalorie diet does not appear to have an adverse effect on insulin sensitivity); it is also important to distribute meals correctly throughout the day, with the greater supply of calories in the first half of the day and including breakfasts rich in products with a low glycemic index (Gołąbek, Regulska-Ilow, 2019). When assessing the practical effectiveness of the recommended modifications, it is worth quoting the results of a study conducted among PCOS patients and support groups, which showed that although most of them try to implement dietary recommendations, they achieve their health goals only in a small percentage (about 12\%) (Arentz, Smith, Abbott, Bensoussan, 2021). This indicates the need for close multidisciplinary cooperation between physicians, dieticians, psychologists, physiotherapists and personal trainers in caring for these patients.

The primary drug in the treatment of patients with the metabolic phenotype of PCOS is metformin, whereas the proposed second-line treatment is low-dose hormonal contraception (Milewicz et al., 2018). Metformin acts in a multi-directional way by inhibiting the production of glucose by the liver (by inhibiting glycogenolysis and gluconeogenesis), increasing the sensitivity of tissues to insulin (by increasing peripheral glucose uptake and tissue consumption), inhibiting glucose absorption (by delay its absorption in the intestine), stimulation of intracellular glycogen synthesis and increasing the capacity for transmembrane glucose transport (by activating all glucose transporters), together with beneficial effects on the lipid profile and weight reduction; the drug also reduces the production of androgens by the adrenal glands and ovaries. Metformin may also increase the ovulation rate in patients with PCOS (Cwynar-Zając, 2021). Indications for the use of metformin in Poland include - in addition to the treatment of diabetes and insulin resistance - also PCOS therapy, however in children and adolescents they are limited to the treatment of diabetes after the age of 10. The authors of Polish Position Statement (Milewicz at al., 2018) emphasize that metformin is not a first-line drug in women with oligoovulation, hyperandrogenism and infertility. Nevertheless, other Polish authors (Otto-Buczkowska, Grzyb, Jainta, 2018) believe metformin should be the first-line drug in young girls with POCS, which can be used both as monotherapy and in combination with anti-androgens. In recent years, there has been an increased interest in the use of GLP-1 receptor agonists and inositols in PCOS patients with insulin resistance and disorders of carbohydrate metabolism. Meta-analysis of the studies conducted so far shows that GLP-1 analogues are more effective than metformin in terms of weight reduction and improvement of insulin sensitivity in overweight or obese PCOS patients. Combined use of these drugs is also beneficial (Ma, 
Ding, Wang, Deng, Sun, 2021). Another metaanalysis and systematic review of studies on the comparison of the effectiveness of myo-inositol and metformin showed no significant advantage of any of the drugs in terms of the effect on the hormonal profile and ovarian function, however indicating that myo-inositol may be more effective in improving fertility (Azizi Kutenaei, Hosseini Teshnizi, Ghaemmaghami, Eini, Roozbeh, 2021). In a study conducted in a group of girls and women with PCOS aged 14-48 years, beneficial metabolic effects of inositol were found (improvement of insulin sensitivity, reduction of glucose, insulin and glycosylated hemoglobin concentrations, with no effect on lipid metabolism) compared with the combined contraceptive pill (increase in serum cholesterol and triglycerides, worsening of insulin resistance) and an untreated control group (De Diego, Gómez-Pardo, Groar, López-Escobar, Martín-Estal et al., 2020). The authors of the latter publication indicate that the current recommendations and clinical practice in the case of PCOS are not sufficiently focused on the treatment and prevention of hormonal and metabolic disorders. It is worth emphasizing that all the above-mentioned therapeutic options were included in the Position Statement of PDE, PSGO and PSGE, published 3 years ago (Milewicz et al., 2018).

In women whose main problem is hyperandrogenism, most recommendations (Conway et al., 2014; Fauser, 2004; Milewicz et al., 2018) advise the two-component contraceptive therapy, with progestogen of anti-androgenous activity. However, the greater risk of deep vein thrombosis should be taken into account when using preparations with an anti-androgenic component (drospirenone, cyproterpone acetate), and also containing gestodene and desogestrel, than using most androgenic progestogens (lewonorgestrel, norethisterone, norgestimate) (Peña et al., 2020). There are also important contraindications to the use of hormonal contraception related to the action of the estrogen component, which may be partially limited while maintaining the efficacy of therapy by reducing the dose of ethinylestradiol from 30-35 $\mu \mathrm{g}$ to $20 \mu \mathrm{g}$ (Milewicz et al., 2018). Apart from the increased risk of thrombosis, the negative influence of contraceptives on the lipid metabolism (increase in total cholesterol and LDL-cholesterol fraction) is emphasized together with deterioration of insulin sensitivity, both in the fasting state (increased HOMA index), as well as after an oral glucose load. This leads in the long term to an increased risk of cardiovascular diseases, which may be particularly unfavorable in overweight and obese patients who experience cumulative metabolic complications of obesity and used hormonal therapy. In recent years after the publication of these recommendations - the study on adolescents has been published, indicating greater effectiveness of therapy aimed at correcting metabolic disorders vs. hormonal contraception with regard to the restoration of ovulation and their comparable effectiveness in the reduction of hyperandrogenism (Ibáñez, Díaz, GarcíaBeltrán, Malpique, Garde et al., 2020). Issues related to PCOS therapy in adolescents will be presented in detail later in this paper. 
Another therapeutic option is the use of spironolactone - a diuretic, the actions of which also include inhibition of androgen secretion and their binding to receptors in hair follicles, as well as inhibition of 5a-reductase activity; it is recommended to add a contraceptive at the same time (Milewicz et al., 2018). Due to the relatively long time of therapy required to reduce the clinical symptoms of hyperandrogenism, especially hirsutism, it is advisable to perform cosmetic procedures (laser epilation, eflornithine).

In women with a reproductive phenotype, the primary goal of PCOS therapy is to restore ovulation. In obese patients, the mainstay of treatment is lifestyle modification, usually with the addition of pharmacotherapy with metformin. In the next stage, drugs that induce FSH secretion are used - clomiphene citrate and letrozole; laparoscopic ovarian cauterization can also be performed (Milewicz et al., 2018). The authors of a meta-analysis involving 4,168 patients and 8,310 stimulated cycles showed that letrozole was more effective in inducing ovulation than clomiphene, noting that both in Europe and in the USA the drug is used in this indication "off-label" (Tsiami, Goulis, Sotiriadis, Kolibianakis, 2021). Similar observations were presented several years earlier by Hilgers (2004), who also compared the different dosing regimens and noted the possible reduction in the thickness of the endometrium in patients receiving clomiphene. Recent studies have confirmed greater endometrial receptivity during the "implantation window" in women with PCOS after using letrozole compared to clomiphene (Wang, Lv, Li, Bai, Yang, 2021). A detailed discussion of these issues is beyond the scope of this paper.

It seems that although the determination of the reproductive phenotype of PCOS will concern mainly women of reproductive age who are trying to get pregnant, restoring ovulation (and in a broader perspective - fertility) may be a more important goal in terms of reproductive health than just obtaining regular bleeding and reduce the severity of hyperandrogenisation symptoms at any stage of life. This approach is confirmed in the latest publications on the therapeutic management of girls with PCOS (Calcaterra, Verduci, Cena, Magenes, Todisco, 2021b; Ibáñez et al., 2020). To improve the general health of patients, it is also important to correct metabolic disorders and reduce cardiovascular risk, which is not achieved with the use of hormonal contraception only.

\section{Hyperandrogenism and PCOS-related metabolic disorders in adolescents - therapeutic options}

As mentioned before, the initial symptoms of PCOS - irregular and often monophasic cycles, acne and discrete hirsutism - are to some extent similar to the changes observed during normal puberty. However, a recently published study of Polish authors (Milczarek, Kucharska, Borowiec, 2019) showed that in girls with suspected PCOS, the combined occurrence of menstrual disorders and hirsutism is associated with an increased risk of 
laboratory-confirmed hyperandrogenism. The maintenance or progression of these symptoms over a longer period of observation, as well as disturbances in the metabolic profile of patients (not included in the criteria for the diagnosis of PCOS) are also of great importance. Obesity and metabolic disorders should be included in the diagnostic and therapeutic process in girls with suspected PCOS not only as components of this syndrome, but primarily as risk factors for diabetes, cardiovascular diseases and infertility later in life (Otto-Buczkowska et al., 2018). Research by Polish authors (Drosdzol-Cop, TymińskaBandoła, Bil, Stojko, Skrzypulec-Plinta, 2017) showed that up to $80 \%$ of girls with PCOS were overweight or obese. Otherwise, in earlier American research (Hoeger, 2007), impaired glucose tolerance was observed in approximately $40 \%$ of obese teenagers with PCOS.

As in the case of adult women, in the treatment of PCOS patients in developmental age, lifestyle modification is essential, achieved primarily through the implementation of a properly balanced diet (changing eating habits) and increasing physical activity. The need to pay attention to the emotional disorders observed in these girls is also emphasized (Peña et al., 2020). Detailed dietary recommendations are aimed at reducing the glycemic load in meals (consuming complex carbohydrates from unprocessed foods), prolonged gastric emptying time (consumption of fiber, especially soluble fiber), as well as ensuring an optimal supply of vitamins, microelements, polyunsaturated fatty acids and other nutrients. More and more attention is paid to dietary supplements with beneficial effects in patients (including teenagers) with obesity and PCOS (inositols, omega-3 fatty acids, berberine, curcumin), using pre- and probiotics and maintaining an optimal gut microbiome. The use of nutritional therapy and dietary supplements in teenagers with PCOS and insulin resistance is treated as a preventive action aimed at restoring ovulation and protecting the fertility of these girls (Calcaterra et al., 2021b).

Current recommendations include the use of two-component contraception with a progestogen component with anti-androgenic effect as first-line pharmacotherapy in girls with PCOS in the $4-5^{\text {th }}$ stage of puberty, in the same time paying attention to the potential side effects of these preparations and the small number of randomized clinical trials in this age group (Hecht Baldauff, Arslanian, 2015; Ibáñez et al., 2017; Milewicz et al., 2018). Despite the beneficial effects of using anti-androgen preparations, Milewicz et al. (2018) emphasize that the use of preparations containing ethinylestradiol and levonorgestrel in adolescents reduces the risk of thrombosis. In turn, Ibáñez et al. (2017) point at a particularly unfavorable effect of cyproterone acetate on the lipid metabolism and conclude that the use of hormonal contraception actually leads to pseudo-normalization of the menstrual pattern and anovulation-related infertility. Hecht Baldauff i Arslanian (2015) recommend conducting a detailed family history of thrombotic diseases and exclusion of factor V Leyden deficiency. Peña et al. (2020) indicate the legitimacy of choosing preparations containing $30 \mu \mathrm{g}$ of ethinylestradiol and "low-risk" progestogens (levonorgestrel, norethisterone, norgestimate). 
All the authors pay attention to the small number of randomized trials on the use of combined contraceptive pills in girls.

The present study, which is a review of current medical recommendations, does not deal with bioethical issues, however, in the case of using hormonal contraception, these problems are important enough that they should be taken into account when deciding on the type of therapy.

In girls with PCOS, progesterone may be used in the second phase of the cycle to achieve regular monthly bleeding (Milewicz et al., 2018). However, this recommendation does not seem fully feasible, taking into account the high frequency of monophasic cycles and the prolongation of the follicular phase in ovulatory cycles typical of PCOS, whereas administration of progesterone to achieve regular bleeding requires its use on a regular schedule, usually from day 16 to day 25 of the cycle, regardless of the appearance of ovulation.

Another potential option is the use of anti-androgenic preparations (flutamide, finasteride, cyproterone acetate in high doses), which are not currently approved for the treatment of girls and adolescents; however, clinical trials are conducted on their use in the case of particularly severe symptoms of hyperandrogenism. A study conducted in the Swedish population showed that the initiation of therapy with anti-androgen preparations in girls under 18 years of age increases the chances of obtaining natural (spontaneous) conception, in comparison with women who started treatment later (the analysis included patients using various preparations: combined contraceptive pills containing ethinylestadiol and dienogest, drospirenone or desogestrel, as well as spironolactone, cyproterone acetate, finasteride and dutasteride, eflornithine, flutamide and bicalutamide) (Elenis, Desroziers, Persson, Sundström Poromaa, Campbell, 2021).

A group of researchers led by Ibañez, who has been dealing with PCOS in girls for many years, has published in recent years the results of studies comparing various pharmacotherapy methods in girls with PCOS. The first study showed that combined contraceptive pills and metformin had a similar effect on reducing hirsutism and improving lipid metabolism indicators, but metformin produced a greater reduction in obesity as expressed by a reduction in body mass index (BMI), while the use of oral contraception allowed for greater regularity of menstrual cycles and a greater reduction in the severity of acne (Ibáñez et al., 2017). The results of another study comparing the effects of using a combined contraceptive pill (containing ethinylestradiol and levonorgestrel) and combined SPIOMET therapy (i.e. spironolactone at a dose of $50 \mathrm{mg} /$ day, pioglitazone at a dose of 7.5 $\mathrm{mg}$ /day and metformin at a dose of $850 \mathrm{mg}$ /day), aimed primarily at correcting metabolic disorders, in non-obese girls with PCOS seem to be particularly interesting. (Ibáñez et al., 2020). Both pharmacotherapy methods have been shown to be similarly effective in terms of the effect on body weight (fat and lean body mass) and the reduction of androgen levels. 
However, in the case of SPIOMET therapy, a better reduction of visceral adipose tissue and insulin secretion was achieved. During the first year after the end of treatment, a 3-fold higher frequency of ovulation was found in the group of girls who received SPIOMET therapy than in the group of girls who used contraceptive pills, moreover - normoovulation was achieved only in patients from the SPIOMET group, while the frequency of anovulation was 10 times higher in the group previously receiving hormonal contraception. It is worth emphasizing once again that this study did not include obese girls, who should be expected to experience more severe metabolic disorders. In another study, the same group (Díaz, Bassols, López-Bermejo, De Zegher, Ibáñez, 2020) assessed the profile of circulating microRNAs in girls with PCOS and found reduced levels of miR-451a in them. Researchers proposed to calculate a "metabolic health index" from miR-451a expression and fasting insulin concentration. The values of this index turned out to be significantly higher after the end of SPIOMET therapy than in the group after hormonal contraception. As the conclusions of the conducted research, the authors of the discussed report emphasized the advantage of SPIOMET therapy over the use of hormonal contraception in girls with PCOS in terms of increased insulin sensitivity and a greater frequency of normal ovulations, which also persisted after the therapy withdrawal. At the same time, they warn against initiating PCOS therapy with oral contraception, which leads to reduced fertility due to anovulation or oligoovulation and, as a consequence, to the use of assisted reproductive techniques, which is associated with an increased risk of complications and potentially with consequences for the lifetime in offspring (Ibáñez et al., 2020). These conclusions are important in terms of implementing - also in adolescents - hormonal contraception in order to "regulate menstruations", sometimes without full diagnostics and for many years. Taking into account the mechanism of their action, consisting in inhibiting ovulation by blocking the cyclical activity of the pituitary and ovaries, and achieving regular "withdrawal" bleeding, the possibility of a quick, spontaneous return of normal ovulation cycles shortly after the withdrawal of contraception in patients with previous menstrual disorders in the course of PCOS may raise some doubts. When planning the implementation of such therapy, however, one should take into account the limitations of using both pioglitazone (in Poland, the registration indications cover only the treatment of type 2 diabetes in adults as a second- or third-line drug), and spironolactone (it is necessary to avoid the use of the drug during pregnancy due to the risk of feminization of male fetuses and the potential reduction of placental perfusion).

According to the current state of knowledge, the therapy of girls with PCOS should be conducted comprehensively, including lifestyle and dietary modifications, as well as pharmacotherapy aimed at correcting metabolic disorders and reducing the severity of hyperandrogenism, with the aim of restoring ovulation and the proper fertility potential. 


\section{PCOS risk factors in girls - the possibilities of prevention}

It is known that premature onset of the adrenal phase of puberty (adrenrche), i.e. the presence of pubic hair in girls before the age of 8 , may precede the occurrence of PCOS, however, on the other hand, this syndrome only develops in some patients with premature adrenarche (Ibáñez et al., 2017; Oberfield, Sopher, Gerken, 2011). The risk of PCOS in this group of girls is especially increased in the case of persistent hyperandrogenism and obesity. Such girls require the exclusion of non-classical CAH and - in justified cases - Cushing's syndrome. At the same time, it should be borne in mind that the earlier age of adrenarche is correlated with higher BMI values (Hoeger, 2007). Higher testosterone levels were also found in obese girls compared to the control group of girls with normal body weight at the same age, wherein these differences were significant already at the age of 8 and were maintained throughout adolescence (Reinehr, de Sousa, Roth, Andler, 2005). Obese girls in the early stages of puberty had lower levels of sex hormone binding protein (SHBG) and higher FAI values, as well as many times greater insulin secretion after intravenous glucose load than girls with normal body weight at the same stage of puberty (Nokoff, Thurston, Hilkin, Pyle, Zeitler et al., 2019). It is also known that children with low birth weight for gestational age (SGA) and/or intrauterine growth restriction (IUGR) are at increased risk of hyperandrogenism, insulin resistance, premature pubarche and PCOS. For the normal course of adolescence, proper nutrition of children in the early stages of life is also important. A lower incidence of premature puberty in breastfed girls and an earlier onset of puberty in overfed infants were observed (Calcaterra, Cena, Regalbuto, Vinci, Porri i in., 2021a).

\section{PCOS risk factors in fetal life - the possibilities of prevention}

Pregnancy is the period during which the mother's organism prepares the fetus for life in an external environment. This specific programming of the mechanisms of coping with the effects of unfavorable factors takes place largely with the participation of epigenetic changes that permanently affect the expression of genes: DNA methylation, modification of histone proteins, activation or silencing of genes with the participation of non-coding RNAs (D. Goyal, Limesand, R. Goyal, 2019). According to the historical "thrifty phenotype" hypothesis, insulin resistance is to be an adaptive mechanism ensuring the redistribution of glucose to the brain in the case of fetal malnutrition. (Barker, 2002). In animal studies, fetal hypotrophy has been shown to be associated with altered expression of certain micro-RNAs (e.g. miR-29a), leading to reduced cellular glucose utilization (which in turn is one of the mechanisms leading to the development of insulin resistance), as well as with disorders of methylation of key genes for metabolism, where these patterns persist in later periods of life (Vaiserman, Lushchak, 2019; Zhou, Gu, Shi, Li, Hao et al., 2016). Similar are adverse effects 
of obesity or overweight in the mother before pregnancy, as well as the mother's diet during pregnancy rich in sugars and fats. These situations are associated with the supply of excessive amounts of energy in the form of glucose and fats to the placenta and the fetus, which results in reprogramming of metabolism and appetite regulation with a significant contribution from epigenetic mechanisms (Şanlı, Kabaran, 2019). The authors of the cited study emphasize the need to control the mother's body weight before and during pregnancy, which, along with healthy nutrition, can improve the "metabolic environment", contributing to the reduction of the risk of metabolic disorders programmed in fetal life.

It is known that daughters of mothers with PCOS have elevated AMH levels after birth and hyperandrogenism and insulin resistance later in life. In genome wide association studies (GWAS) 19 genes related to the risk of PCOS, located on neuroendocrine, metabolic and reproductive pathways were identified (Hiam, Moreno-Asso, Teede, Laven, Stepto et al., 2019), however, despite the high frequency of inheritance of PCOS (about 70\%), its genetic background has been documented only in $10 \%$ of cases. Nevertheless, gene methylation disturbances were found to be associated with the risk of PCOS in the GWAS studies, and confirmed or postulated epigenetic mechanisms include, among others, hypomethylation of LH/hCG receptor genes (leading to increased androgens secretion stimulated by LH) and changes in methylation of $\mathrm{AMH}, \mathrm{AMH}$ receptor and insulin receptor genes. Exposure of the fetus to the excess of androgens is also of particular importance (Abbott, Kraynak, Dumesic, Levine, 2019). These reports indicate that some of the factors leading to PCOS, previously considered hereditary, are modifiable, which implies the possibility of preventing the transmission of PCOS from mother to daughter in the next generations.

\section{Summary}

Polycystic ovary syndrome is a disease of multifactorial etiology, the pathomechanism of which involves the action of genetic (mainly epigenetic) and environmental factors, starting from the perioconceptive or even preconcepive, embryonic and fetal period, through childhood and adolescence, with full manifestation in women of reproductive age. The clinical picture of this syndrome in girls is different from its course in adult women, and some physiological symptoms found in the first years after menarche (irregular menstruations, monophasic cycles, severe acne, polycystic structure of the ovaries) are the basis for the diagnosis of PCOS in adult women. Criteria for the diagnosis of PCOS in adolescents have been developed, however, it is also necessary to provide long-term observation and appropriate therapy for girls from the "PCOS risk group" who only partially meet these criteria.

The recommendations of international scientific societies regarding PCOS therapy in adolescents have so far proposed the use of hormonal contraception as the first-line 
treatment. In recent years, more and more attention has been paid to the need to take into account metabolic disorders (obesity, insulin resistance or glucose intolerance) in therapeutic management. It is necessary to implement a comprehensive management, including modification of lifestyle and eating habits, and - additionally - pharmacotherapy aimed primarily at correcting metabolic disorders. In the most recent reports (Calcaterra i in., 2021b; Ibáñez et al., 2020) the aspect of focusing the therapy on restoring or obtaining fertility in adolescents, and not only in women trying to become pregnant (often after many years of uninterrupted use of hormonal contraception, not always preceded by full PCOS diagnostics) is also underlined. The authors directly emphasize the negative impact of hormonal contraception on the possibility of ovulation within at least a few months after discontinuation of contraception (Ibáñez in., 2020). Nutritional therapy is also of particular importance in the aspect of fertility protection (Calcaterra et al., 2021b). The implementation of these important recommendations should contribute to the improvement of the reproductive health of adult women with PCOS and metabolic disorders related to this disease, as well as of girls diagnosed with PCOS or at increased risk of PCOS. Appropriate therapeutic management in patients with PCOS may lead not to only faster obtaining pregnancy, but also to reducing the incidence of PCOS in their daughters.

\section{Bibliography:}

Abbott, D.H., Kraynak, M., Dumesic, D.A., Levine, J.E. (2019). In utero Androgen Excess: A Developmental Commonality Preceding Polycystic Ovary Syndrome? Frontiers of Hormone Research, 53, 1-17, https:// doi.org/10.1159/000494899.

Arentz, S., Smith, C.A., Abbott, J., Bensoussan, A. (2021). Perceptions and experiences of lifestyle interventions in women with polycystic ovary syndrome (PCOS), as a management strategy for symptoms of PCOS, BMC Womens. Health, 21, 1-8, https://doi.org/10.1186/s12905-021-01252-1.

Azizi Kutenaei, M., Hosseini Teshnizi, S., Ghaemmaghami, P., Eini, F., Roozbeh, N. (2021).

The effects of myo-inositol vs. metformin on the ovarian function in the polycystic ovary syndrome: A systematic review and meta-analysis, European Reviev for Medical and Pharmacological Sciences, 25, 3105-3115, https:// doi.org/

10.26355/eurrev_202104_25565.

Azziz, R., Carmina, E., Dewailly, D., Diamanti-Kandarakis, E., Escobar-Morreale, H.F., Futterweit, W., Janssen, O.E., Legro, R.S., Norman, R.J., Taylor, A.E., Witchel, S.F. (2009). The Androgen Excess and PCOS Society criteria for the polycystic ovary syndrome: the complete task force report, Fertility and Sterility, https://doi.org/10.1016/j.fertnstert.2008.06.035.

Barker, D.J.P. (2002). Fetal programming of coronary heart disease, Trends in Endocrinology $\mathcal{E}$ Metabolism, 13, 364-368, https:// doi.org/10.1016/s1043-2760(02)00689-6. 
Bozdag, G., Mumusoglu, S., Zengin, D., Karabulut, E., Yildiz, B.O. (2016). The prevalence and phenotypic features of polycystic ovary syndrome: A systematic review and meta-analysis, Human Reproduction, 31, 2841-2855, https:/ / doi.org/

10.1093/humrep/dew218.

Calcaterra, V., Cena, H., Regalbuto, C., Vinci, F., Porri, D., Verduci, E., Chiara, M., Zuccotti, G.V. (2021a). The role of fetal, infant, and childhood nutrition in the timing of sexual maturation, Nutrients, 13, 419, https:// doi.org/10.3390/nu13020419.

Calcaterra, V., Verduci, E., Cena, H., Magenes, V.C., Todisco, C.F., Tenuta, E., Gregorio, C., De Giuseppe, R., Bosetti, A., Di Profio, E., Zuccotti, G. (2021b). Polycystic ovary syndrome in insulin- resistant adolescents with obesity: The role of nutrition therapy and food supplements as a strategy to protect fertility, Nutrients, 13, 1848, https://doi.org/10.3390/nu13061848.

Christensen, S.B., Black, M.H., Smith, N., Martinez, M.M., Jacobsen, S.J., Porter, A.H., Koebnick, C. (2013). Prevalence of polycystic ovary syndrome in adolescents, Fertility and Sterility, 100, 470-477, https:// doi.org/10.1016/j.fertnstert.2013.04.001.

Cwynar-Zając, Ł. (2021). Metformin - a new approach. Pediatric Endocrinology Diabetes and Metabolism, 27 (2), 134-140, https://doi.org/10.5114/pedm.2021.107166.

Conway, G., Dewailly, D., Diamanti-Kandarakis, E., Escobar-Morreale, H.F., Franks, S., Gambineri, A., Kelestimur, F., Macut, D., Micic, D., Pasquali, R., Pfeifer, M., Pignatelli, D., Pugeat, M., Yildiz, B.O. (2014). The polycystic ovary syndrome: A position statement from the European Society of Endocrinology, European Journal of Endocrinology, 171, 1-29, https://doi.org/10.1530/EJE-14-0253.

De Diego, M.V., Gómez-Pardo, O., Groar, J.K., López-Escobar, A., Martín-Estal, I., CastillaCortázar, I., Rodríguez-Zambrano, M.Á. (2020). Metabolic impact of current therapeutic strategies in Polycystic Ovary Syndrome: a preliminary study, Archives of Gynecology and Obstetrics, 302, 1169-1179, https://doi.org/10.1007/s00404-020-05696$\mathrm{y}$.

Díaz, M., Bassols, J., López-Bermejo, A., De Zegher, F., Ibáñez, L. (2020). Low Circulating Levels of miR-451a in Girls with Polycystic Ovary Syndrome: Different Effects of Randomized Treatments, Journal of Clinical Endocrinology and Metabolism, 105, 273-281, https://doi.org/10.1210/clinem/dgz204.

Drosdzol-Cop, A., Tymińska-Bandoła, A., Bil, A., Stojko, R., Skrzypulec-Plinta, V. (2017). Zespół policystycznych jajników u nastolatek - diagnostyka i leczenie, Ginekologia po Dyplomie, https://podyplomie.pl/ginekologia/26793,zespol-policystycznychjajnikow-u-nastolatek-diagnostyka-i-leczenie.

Elenis, E., Desroziers, E., Persson, S., Sundström Poromaa, I., Campbell, R.E. (2021). Early initiation of anti-androgen treatment is associated with increased probability of spontaneous conception leading to childbirth in women with polycystic ovary 
syndrome: a population-based multiregistry cohort study in Sweden, Human Reproduction, 36, 1427-1435, https://doi.org/10.1093/humrep/deaa357.

Fauser, B.C.J.M. (2004). Revised 2003 consensus on diagnostic criteria and long-term health risks related to polycystic ovary syndrome, Fertility and Sterility, 81, 19-25, https://doi.org/10.1016/j.fertnstert.2003.10.004.

Gołąbek, K.D., Regulska-Ilow, B. (2019). Dietary support in insulin resistance: An overview of current scientific reports, Advances in Clinical and Experimental Medicine, 28, 15771585, https:// doi.org/10.17219/ ACEM/109976.

Goyal, D., Limesand, S.W., Goyal, R. (2019). Epigenetic responses and the developmental origins of health and disease, Journal of Endocrinology, 242, T105-T119, https://doi.org/10.1530/JOE-19-0009.

Hecht Baldauff, N., Arslanian, S. (2015). Optimal management of polycystic ovary syndrome in adolescence, Archives of Disease in Childhood, 100, 1076-1083, https://doi.org/10.1136/archdischild-2014-306471.

Hiam, D., Moreno-Asso, A., Teede, H.J., Laven, J.S.E., Stepto, N.K., Moran, L.J., GibsonHelm, M. (2019). The Genetics of Polycystic Ovary Syndrome: An Overview of Candidate Gene Systematic Reviews and Genome-Wide Association Studies, Journal of Clinical Medicine, 8, 1606, https:/ / doi.org/10.3390/jcm8101606.

Hickey, M., Doherty, D.A., Atkinson, H., Sloboda, D.M., Franks, S., Norman, R.J., Hart, R. (2011). Clinical, ultrasound and biochemical features of polycystic ovary syndrome in adolescents: Implications for diagnosis, Human Reproduction, 26, 1469-1477, https://doi.org/10.1093/humrep/der102.

Hilgers, T. (2004). Medical Treatment of Ovarian and Target Organ Dysfunction (in:) Hilgers T. (ed.) The Medical \& Surgical Practice of NaProTECHNOLOGY, 607-633, Pope Paul VI Institute Press, Omaha, Nebraska, USA.

Hoeger, K.M. (2007). Obesity and lifestyle management in polycystic ovary syndrome,

Clinical Obstetrics and Gynecology, 50, 277-294, https:/ / doi.org/

10.1097/GRF.0b013e31802f54c8.

Ibáñez, L., Díaz, M., García-Beltrán, C., Malpique, R., Garde, E., López-Bermejo, A., de Zegher, F. (2020). Toward a Treatment Normalizing Ovulation Rate in Adolescent Girls With Polycystic Ovary Syndrome, Journal of the Endocrine Society, 4, 1-9, https://doi.org/10.1210/jendso/bvaa032.

Ibáñez, L., Oberfield, S.E., Witchel, S., Auchus, R.J., Chang, R.J., Codner, E., Dabadghao, P., Darendeliler, F., Elbarbary, N.S., Gambineri, A., Garcia Rudaz, C., Hoeger, K.M., López-Bermejo, A., Ong, K., Peña, A.S., Reinehr, T., Santoro, N., Tena-Sempere, M., Tao, R., Yildiz, B.O., Alkhayyat, H., Deeb, A., Joel, Di., Horikawa, R., De Zegher, F., Lee, P.A. (2017). An International Consortium Update: Pathophysiology, Diagnosis, 
and Treatment of Polycystic Ovarian Syndrome in Adolescence, Hormone Research in Paediatrics, 88, 371-395, https:/ / doi.org/10.1159/000479371.

Khashchenko, E., Uvarova, E., Vysokikh, M., Ivanets, T., Krechetova, L., Tarasova, N., Sukhanova, I., Mamedova, F., Borovikov, P., Balashov, I., Sukhikh, G. (2020). The Relevant Hormonal Levels and Diagnostic Features of Polycystic Ovary Syndrome in Adolescents, Journal of Clinical Medicine, 9, 1831, https://doi.org/10.3390/jcm9061831. Lewandowski, K.C., Cajdler-Łuba, A., Salata, I., Bieńkiewicz, M., Lewiński, A. (2011). The utility of the gonadotrophin releasing hormone $(\mathrm{GnRH})$ test in the diagnosis of polycystic ovary syndrome (PCOS), Endokrynologia Polska, 62, 120-128.

Ma, R., Ding, X., Wang, Y., Deng, Y., Sun, A. (2021). The therapeutic effects of glucagon-like peptide-1 receptor agonists and metformin on polycystic ovary syndrome, Medicine (Baltimore), 100, e26295, https://doi.org/10.1097/md.0000000000026295.

Milczarek, M., Kucharska, A., Borowiec, A. (2019). Difficulties in diagnostics of polycystic ovary syndrome in adolescents - a preliminary study, Pediatric Endocrinology, Diabetes and Metabolism, 25 (3), 122-126, https://doi.org/10.5114/pedm.2019.87177.

Milewicz, A., Kudła, M., Spaczyński, R.Z., Dębski, R., Męczekalski, B., Wielgoś, M., Ruchała, M., Małecka-Tendera, E., Kos-Kudła, B., Jędrzejuk, D., Zachurzok, A. (2018). Stanowisko Polskiego Towarzystwa Endokrynologicznego, Polskiego Towarzystwa Ginekologów i Położników oraz Polskiego Towarzystwa Endokrynologii Ginekologicznej w sprawie diagnostyki i leczenia zespołu policystycznych jajników, Endokrynologia Polska, 69, 328-336, https:// doi.org/10.5603/ep.2018.0046.

Nokoff, N., Thurston, J., Hilkin, A., Pyle, L., Zeitler, P.S., Nadeau, K.J., Santoro, N., Kelsey, M.M. (2019). Sex Differences in Effects of Obesity on Reproductive Hormones and Glucose Metabolism in Early Puberty, Journal of Clinical Endocrinology and Metabolism, 104, 4390-4397, https://doi.org/10.1210/jc.2018-02747.

Oberfield, S.E., Sopher, A.B., Gerken, A.T. (2011). Approach to the girl with early onset of pubic hair, Journal of Clinical Endocrinology and Metabolism, 96, 1610-1622, https:// doi.org/10.1210/jc.2011-0225.

Otto-Buczkowska, E., Grzyb, K., Jainta, N. (2018). Polycystic ovary syndrome (PCOS) and the accompanying disorders of glucose homeostasis among girls at the time of puberty, Pediatric Endocrinology Diabetes and Metabolism, 24 (1), 38-42, https://doi.org/10.18544/PEDM-24.01.0101.

Pasquali, R. (2006). Obesity and androgens: facts and perspectives, Fertility and Sterility, 85, 1319-1340, https://doi.org/10.1016/j.fertnstert.2005.10.054.

Peña, A.S., Witchel, S.F., Hoeger, K.M., Oberfield, S.E., Vogiatzi, M.G., Misso, M., Garad, R., Dabadghao, P., Teede, H. (2020). Adolescent polycystic ovary syndrome according to the international evidence-based guideline, BMC Medicine, 18, 72, https:/ / doi.org/10.1186/s12916-020-01516-x. 
Reinehr, T., de Sousa, G., Roth, C.L., Andler, W. (2005). Androgens before and after weight loss in obese children, Journal of Clinical Endocrinology and Metabolism, 90, 5588-5595, https://doi.org/10.1210/jc.2005-0438.

Şanl1, E., Kabaran, S. (2019). Maternal Obesity, Maternal Overnutrition and Fetal

Programming: Effects of Epigenetic Mechanisms on the Development of Metabolic

Disorders, Current Genomics, 20, 419-427, https:/ / doi.org/10.2174/

1389202920666191030092225.

Stein, I.F., Leventhal, M.L. (1935). Amenorrhoea associated with bilateral polycystic ovaries, American Journal of Obstetrics and Gynecology, 29, 181-191.

Tsiami, A.P., Goulis, D.G., Sotiriadis, A.I., Kolibianakis, E.M. (2021). Higher ovulation rate with letrozole as compared with clomiphene citrate in infertile women with polycystic ovary syndrome: a systematic review and meta-analysis, Hormones, https://doi.org/10.1007/s42000-021-00289-z.

Urbańska, E., Hirnle, L., Olszanecka-Glinianowicz, M., Skrzypulec-Plinta, V., SkrzypulecFrankel, A., Drosdzol-Cop. A (2019). Is polycystic ovarian syndrome and insulin resistance associated with abnormal uterine bleeding in adolescents? Ginekologia Polska, 90, 262-269, https:// doi.org/10.5603/GP.2019.0049.

Vaiserman, A., Lushchak, O. (2019). Prenatal malnutrition-induced epigenetic dysregulation as a risk factor for type 2 diabetes, International Journal of Genomics, https:// doi.org/10.1155/2019/3821409.

Wang, L., Lv, S., Li, F., Bai, E., Yang, X. (2021). Letrozole Versus Clomiphene Citrate and Natural Cycle: Endometrial Receptivity During Implantation Window in Women With Polycystic Ovary Syndrome, Frontiers in Endocrinology (Lausanne), 11, https://doi.org/10.3389/fendo.2020.532692.

Witchel, S.F., Oberfield, S., Rosenfield, R.L., Codner, E., Bonny, A., Ibáñez, L., Pena, A., Horikawa, R., Gomez-Lobo, V., Joel, D., Tfayli, H., Arslanian, S., Dabadghao, P., Garcia Rudaz, C., Lee, P.A. (2015). The Diagnosis of Polycystic Ovary Syndrome during Adolescence, Hormone Research in Paediatrics, 83, 376-389, https://doi.org/10.1159/000375530.

Zhou, Y., Gu, P., Shi, W., Li, J., Hao, Q., Cao, X., Lu, Q., Zeng, Y. (2016). MicroRNA-29a induces insulin resistance by targeting PPARס in skeletal muscle cells, International Journal of Molecular Medicine, 37, 931-938, https://doi.org/10.3892/ijmm.2016.2499. 